\title{
ASPECTOS SEMIÓTICOS PEIRCIANOS DA VERSÃO DA FÍSICA QUÂNTICA COM PREDOMINÂNCIA DA ESCOLA DE COPENHAGUE
}

\section{PEIRCEAN SEMIOTIC ASPECTS FROM QUANTUM PHYSICS APPROACH WITH PREDOMINANCE OF COPENHAGEN SCHOOL}

RESUMO: 0 tema do trabalho presente é a inter-relação de duas noções do real: a filosófica de Charles Sanders Peirce e uma das diversas conceituações da realidade possíveis no interior da Física ou Mecânica Quântica (a da Escola de Copenhague). Ao proceder assim, o propósito geral do nosso estudo é o de elaborar um modelo de real multifacetado. Também interpretamos a dualidade onda-partícula em termos de signos peircianos. Igualmente aspectos da problemática do símbolo são examinados em relação ao modelo proposto. Por fim, o possível papel do Princípio Antrópico na cosmologia é colocado parcialmente em questão.

1 Docente da UFES - Universidade Federal do Espírito Santo. E-mail: lino@npd.ufes.br. 
PALAVRAS-CHAVE: Semiótica; Filosofia; Categorias; Ciência; Realismo.

ABSTRACT: The theme of the present article is the interrelation between two notions of the concept of real: the philosophical one, by Charles Sanders Peirce, and one of the various possible concepts of reality within Physics or Quantum Mechanics (by the so called Copenhagen School). In doing so, the general objective of our study is to elaborate a model for a multifaceted reality. We also interpret the waveparticle duality on the basis of Peircian signs and survey the problem of the symbol in its connection with the model as here proposed. We close the article by partially placing in question the possible role of the Anthropic Principle in cosmology.

KEYWORDS: Semiotic; Philosophy; Categories; Science; Realism.

Não é verdade que só poderemos desenvolver ciência usando apenas os conceitos que são diretamente suscetíveis a experimentos.

Richard Feynman $(2008$, p. 9)

\section{Introdução}

Buscaremos efetuar aqui uma aproximação entre a filosofia de Charles Sanders Peirce (1839-1914) e a Física ou Mecânica Quântica, na elaboração desta que ficou célebre como Interpretação ou Escola de Copenhague, cuja consolidação teórica maior se deu no Congresso de Solvay, Bruxelas, em 1927 (em tal ano, contudo, o nome famoso, associado à capital dinamarquesa, ainda não se estabelecera).

A aproximação acima anunciada fornecerá um contexto abrangente para o desenvolvimento das seguintes alíneas, 
entre mais pontos: a) argumentação de que um fator fundamental do mundo quântico - a dualidade onda-partícula - é, deveras, algo sígnico, o que reforça a hipótese não trivial do filósofo de que o próprio universo já se componha de signos, vale dizer, a chamada "onda de possibilidade" e a sua forma detectada como "corpúsculo", na física atômica e subatômica, são modalidades da iconicidade e da indicialidade peircianas, respectivamente; b) demonstração de que, embora a concepção de continuum fosse cara a Peirce, ela só é passível de aplicação parcial ao domínio dos quanta, pois estes nos obrigam a lidar também com a ideia de descontinuidade; $c$ ) defesa do ponto de vista de que o simbolismo humano, sob a ótica também peirciana, se faz possível porque de antemão existem a iconicidade e a indicialidade referidas atuando no cosmo, além da categoria de Terceiridade; d) exemplificação da alínea anterior, levando em conta a importância da transformação dos fótons de luz em impulsos neurológicos e, logo, em trabalho cerebral.

Reconhecemos de antemão que a nossa perspectiva semiótica (ou peirciano-realista) não acompanha, no fundamental, as atuais (e claro que importantíssimas) discussões de caráter mais analítico e formal a respeito de uma possível ontologia da Física Quântica ${ }^{2}$. Ao invés de confrontá-la com tais discussões (o que exigiria um número considerável de páginas, para além dos limites do nosso já extenso artigo), preferimos manter o foco na presente interpretação do universo dos quanta. Uma vez desenvolvida, tal interpretação poderá ser examinada pelos leitores, convencendo-se estes ou não da

2 Para abordagens em tais direções, consultar o extenso estudo de Krause (2011, p. 95138, cap. 6. "Ontologia e física") e o artigo de Osnaghi (2005, p. 79-125). Um detalhado tratamento pragmatista, embora não semiótico, da Física Quântica, acha-se em Bächold (2008, p. 233-339). Um denso estudo que leva em conta a dimensão da subjetividade nesse campo se encontra em Bitbol (2001, passim). 
sua validade, ou ao menos de parte dela.

Como o nome do fundador do verdadeiro pragmatismo aparece já no primeiro parágrafo deste trabalho, desde agora é prudente algo estar claro: mais do que pragmatista, a nossa orientação segue a postura madura do filósofo ianque, sendo, pois, de natureza semiótica embasada no realismo das suas categorias cenopitagóricas.

\section{Pequena parcela do pensamento de Peirce}

A nossa aproximação de Peirce à Física Quântica fundamentou-se na visão tardia que o filósofo veio a ter da sua tríade de categorias, formuladas, de início, em 1867: tríade que ganhou diversas designações, sendo a principal a da série Primeiridade, Secundidade e Terceiridade. A formulação inicial tornou-se, finalmente, fenomenológica, baseada na percepção humana; com o passar dos anos, todavia, o filósofo deu também um cunho realista às três noções fundamentais do seu sistema de pensamento, e não apenas à segunda delas (cf. IBRI, 1992, p. 55-56).

Esquematizaremos ao máximo a tríade de categorias, sustentadas por Peirce como universais, bem como outros conceitos dele, para apresentar uma síntese do(s) resultado(s) a que chegamos.

A Primeiridade (Firstness) diz respeito ao que for considerado independentemente de outra coisa: na teorização do pensador, trata-se da faceta de feição monádica, aquela que remete ao que se sente como único, muito simples, bastante imediato. Quanto à Secundidade (Secondness), esta abarca o que exista em relação a qualquer outro elemento: tal categoria é apropriada para as experiências diádicas, pondo em jogo pares de objetos. No que concerne à Terceiridade 
(Thirdness), a mesma engloba o que se comporte como uma mediação entre duas coisas: conceitualmente, ela remete às experiências triádicas, as que ligam os integrantes dos pares de elementos (ou de experiências inicialmente diádicas) ( $C P$, $\left.1.300-348^{3}\right)$.

Em estado de Primeiridade, sentimos o mundo sem interpretação; já na condição de Secundidade, discriminamos bem os aspectos do que estivermos examinando; por fim, no âmbito da Terceiridade, mostramo-nos capazes de efetuar generalizações (certas ou erradas) a respeito do material que estudamos (cf. IBRI, 1992, p. 5-6; CP, 5.42). Peirce acreditava que, no seu nível mais fundamental, todos os fatores com que lidamos poderiam ser redutíveis à tríade presente de conceitos, para ele de alcance geral.

Tendo escrito cerca de 80000 páginas ao longo da sua vida, Peirce redefiniu e renomeou muitas das suas ideias de modo incessante, inclusive as que acabamos de esquematizar. Respectivamente, Primeiridade, Secundidade e Terceiridade foram vistas por ele também como Acaso, Existência e Lei (entre mais termos). Dadas as acepções costumeiras destas noções, faria parte da expectativa de muitos que tudo o que chamamos de realidade ficasse restrito à Secundidade ou Existência; não foi, porém, o que aconteceu, à medida que Peirce levava adiante a sua reflexão, com o correr das décadas. A passagem abaixo, de Nathan Houser [s.d.], mostra que o filósofo evoluiu para uma concepção deveras realista das mesmas categorias:

Hacia finales de 1896 Peirce dio lo que Max Fisch ha llama-

3 Referência abreviada aos Collected papers de C. S. Peirce. Ver informação completa no final deste artigo (PEIRCE, 1958). (Em "1.300" há uma remissão ao parágrafo 300 do volume 1 dos textos do filósofo. As demais citações dos CP seguem tal convenção consagrada.). 
do su "paso más decisivo" en su camino hacia un completo realismo: aceptó "lo posible" como un "universo real" y rechazó el punto de vista nominalista según el cual lo posible es meramente aquello que no sabemos que no es verdad. Peirce dio cuenta de ese cambio de ideas [...] y [...] escribió a [William] James que "había alcanzado esa verdad estudiando el problema de los posibles grados de la cantidad, donde me encontré encerrado hasta que pude formar una lógica completa de la posibilidad" [...]. Con esta aceptación de las posibilidades reales, que puso a Peirce en el ala aristotélica del realismo, Peirce se había convertido en lo que Fisch llamó "un realista de tres categorias", que no considera ya lo potencial como aquello que lo real hace ser, y que distingue ahora la universalidad de los primeros de la universalidad de los terceros.

La aceptación de los "posibles" marca una frontera que separa los años de madurez de Peirce de su última época intelectual. $^{4}$

A esta síntese efetuada por Houser acrescentemos a observação de Adriano Duarte Rodrigues: "Podemos relacionar a Primeiridade com aquilo a que Aristóteles e os escolásticos davam o nome de potência [...], definindo-a Peirce de um ponto de vista puramente lógico" (RODRIGUES, 1991, p. 86). Por nosso lado, diremos que a Primeiridade-potência de Peirce remete a um ponto de vista lógico, sem dúvida, mas não apenas: se o "possível" é visto como um "universo real" (HOUSER, [s.d.]), achamo-nos perante uma forte postulação filosófica, de alcance metafísico mesmo; "possível" que é uma das facetas do sistema de um autor "realista de três categorias", criador do que denominamos um "trirrealismo" (MACHADO,

4 Disponível em: www.avizora.com/publicaciones/biografias/textos/textos_p/0029_ peirce_charles_sanders.htm. Acesso em: 07 ago.2013 (grifo nosso). 
2013, p. 8 e 20). ${ }^{5}$

A importância que Peirce deu ao Acaso o fez forjar o termo tychism (tiquismo), cujo étimo grego é deveras "acaso": noção que enfatiza o papel do indeterminismo no universo. A diversidade do cosmo acarreta imperfeições, impossibilidade de uma completa regularidade na manifestação dos fenômenos $(C P, 1.161,1.403,6.74)$.

Outro neologismo de Peirce é synechism (sinequismo), baseado também no grego: synechés significa "contínuo". 0 pensador via uma "continuidade entre os caracteres da mente e da matéria, tal que a matéria nada seria senão mente que teve seus hábitos cristalizados, [...] com um alto e peculiar grau de regularidade mecânica e de rotina" (PEIRCE apud IBRI, 1992, p. 62; $C P, 6.277)$. Além disto, o sinequismo diz respeito à generalidade (Terceiridade), não a um agregado de indivíduos tidos como os únicos fatos reais do mundo, nomeados por um signo de acepção abrangente; o sinequismo ainda conteria a ideia de que o universo experimenta um contínuo crescimento $(C P, 6.102-163,6.602)$.

Quanto ao conceito de signo, observemos uma das formulações do filósofo, mais complexa do que a que postula ser o signo algo (um Primeiro) que, de algum modo, se acha no lugar de outro elemento (um Segundo, chamado objeto), gerando um novo componente (um Terceiro, dito interpretante) (cf. PEIRCE, 1977, p. 46; CP, 2.228). Passemos à formulação, mas não sem antes frisar que o termo Representâmen, de que ele lançará mão, ora parece ter nos seus textos a acepção de "signo", ora a de "signo ainda não atualizado" (PINTO, 1995, p. 46). Ei-la, numa conceituação em geral conhecida como "triângulo semiótico":

5 Às voltas com o audaz neologista que Peirce foi, também nos concedemos a liberdade de criação neológica, neste e em mais artigos em que o filósofo tenha papel acentuado. 
Um Representâmen [Signo] é o Primeiro Correlato de uma relação triádica, o Segundo Correlato sendo chamado de seu Objeto e o possível Terceiro Correlato sendo denominado seu Interpretante, por cuja relação triádica o possível Interpretante é determinado como sendo o Primeiro Correlato da mesma relação triádica para com o mesmo objeto para algum interpretante (apud SANTAELLA, 1995, p. 25; CP, 2.242).

O objeto passa por uma divisão: é imediato ou dinâmico $(C P, 8.183,8.314)$. Objeto imediato: o que se acha disponível no signo de maneira mais direta, situando-se no interior deste; origina-se no objeto dinâmico (real ou imaginário), o qual, localizado no exterior do signo, é o verdadeiro causador da semiose (ou ação sígnica). No cotidiano, ao lidarmos com as coisas (concretas ou não) do real, conseguimos acessá-las à medida que as significamos; assim, o objeto imediato resulta da manipulação mental a que as submetemos, enquanto seres semióticos. Objeto dinâmico é o objeto deflagrador da semiose. Abordamos essa espécie de objeto transformando-o em signo, ou seja, objeto imediato ${ }^{6}$.

0 interpretante sofre uma tripartição: é imediato, dinâmico e final $(C P, 8.314)^{7}$. Interpretante imediato: diz respeito às possibilidades interpretativas do signo. Trata-se do potencial de sentido que deverá atuar em nosso comportamento, uma vez que possuamos um conhecimento mínimo do objeto dinâmico (convertido em imediato) a que o signo remete. Interpretante dinâmico: são as possibilidades interpretativas realmente selecionadas na utilização do signo,

6 Peirce pensou em outras divisões do objeto. 0 imediato poderia ser também: a) descritivo; b) designativo; c) copulante. Por sua vez, o dinâmico se tripartiria em: a) abstrativo; c) concretivo; c) coletivo (cf. SANTAELLA, 1995, p. 57-58, 60).

7 Para outras tripartições do interpretante, cf. Santaella (1995, p. 83-116). 
colhidas do conjunto de virtualidades significativas do interpretante imediato. Interpretante final: concerne ao esgotamento das possibilidades interpretativas do signo. Uma hipótese que vislumbra um eventual conhecimento pleno do objeto dinâmico, exaurindo-o em termos de informação.

Por fim, ícone, índice e símbolo. 0 primeiro destes:

Um Ícone é um Representâmen cuja Qualidade Representativa é uma sua Primeiridade como Primeiro. Ou seja, a qualidade que ele tem qua coisa o torna apto a ser um Representâmen. Assim, qualquer coisa é capaz de ser um Substituto para qualquer coisa com a qual se assemelhe [...]. Um Representâmen apenas por Primeiridade somente pode ter um Objeto similar. [...] Uma simples possibilidade é um Ícone puramente por força de sua qualidade, e seu objeto só pode ser uma Primeiridade. Mas um signo pode ser icônico, isto é, pode representar seu objeto principalmente através de sua similaridade, não importa qual seja seu modo de ser (PEIRCE, 1977, p. 64; CP, 2.276).

O semioticista Júlio Pinto lembra que o traço definidor da "semelhança com o objeto, contudo, não é necessariamente especular, como numa fotografia, embora possa sê-lo" (PINTO, 1995, p. 24, grifo nosso). "Não especular" também deve ser entendido como "não pictórico" (dado importante na Física Quântica, como ainda notaremos). Outra observação do mesmo autor é a de que "existe na identidade do ícone uma relação de analogia, qualquer que seja ela, fazendo de qualquer imagem (visual, auditiva, olfativa, etc.) um ícone em potencial, que depende, para sua atualização, da interferência do sujeito" (PINTO, 1995, p. 24). A analogia existe mesmo no caso em que a semelhança de um ícone com o seu objeto seja "ajudada por regras convencionais", de acordo com o próprio criador da semiótica (PEIRCE, 1977, p. 65; CP, 2.279). Entre 
os muitos exemplos de ícones, temos: quadros, desenhos, imagens, mapas, diagramas, fórmulas matemáticas, estatísticas, esquemas, onomatopeias, comparações, metáforas. (Por nossa conta, adiante defenderemos o ponto de vista de que a matéria em modo ondulatório, tal como o revelado pela Física Quântica, é um ícone situado na própria natureza.)

Passemos ao índice:

Um signo, ou representação, que se refere a seu objeto não tanto em virtude de uma similaridade ou analogia qualquer com ele [caso do ícone], nem pelo fato de estar associado a caracteres gerais que esse objeto acontece ter [caso do símbolo, visto a seguir], mas sim por estar numa conexão dinâmica (espacial inclusive) tanto com o objeto individual, por um lado, quanto, por outro lado, com os sentidos ou a memória da pessoa a quem serve de signo (PEIRCE, 1977, p. 74; $C P, 2.305)$.

Trata-se da modalidade de semiose que envolve ligação mais direta com o seu objeto, nexo existencial com ele, contiguidade; contudo, há relações indiciais que revelam algum elo fixado culturalmente (assim, de novo percebem-se "regras convencionais" em jogo). São casos de índices, produzidos por ações naturais ou não: fumaça (sinal de fogo), pegadas, cata-ventos, sintomas, ponteiros de relógio, dedos apontando, setas, sinais de pontuação, numerais ordinais, pronomes pessoais, demonstrativos e relativos, advérbios de lugar e tempo, datações, nomes próprios, grifos e mais realces de vocábulos, metonímias. (Também por nossa conta, sustentaremos que a matéria, quando em situação do que a Mecânica Quântica denomina partículas ou corpúsculos detectados, tem status de indicialidade.)

Enfim, o símbolo: “[...] um Representâmen cujo caráter 
representativo consiste exatamente em ser uma regra que determinará seu Interpretante. Todas as palavras, frases, livros e outros signos convencionais são Símbolos" (PEIRCE, 1977, p. $71 ; C P, 2.292)$. Com poder de generalidade, eles remetem ao seu objeto por imposição de lei, associação de ideias de natureza arbitrária, convenção. Peirce lida com esse convencionalismo quando medita sobre os signos simbólicos, sem dúvida, mas pensa em algo mais, como demonstra outra passagem dos seus Collected papers: "Creio que a significação que lhe [ao símbolo] atribuo, a de um signo convencional ou de um signo que depende de um hábito (adquirido ou nato), não é tanto um novo significado, mas sim um retorno ao significado original" (PEIRCE, 1977, p. 72, CP, 2.297, grifo nosso). Os termos que ressaltamos mostram que o simbolismo peirciano se fundamenta em hábitos que, em alguns casos, podem resultar de convenções, sim, mas que, em outros, se revelam naturais. A simbolicidade em questão não deve ficar restrita, pois, à questão da arbitrariedade do signo ${ }^{8}$. (Antecipamos, contudo, que, na seção 6 deste artigo, iremos ater-nos precisamente ao forte convencionalismo que é costume enxergar-se numa das modalidades de símbolos - os vocábulos da fala -, com o propósito preciso de conectá-los à própria natureza, à physis, recorrendo ao auxílio maior da Mecânica Quântica e a um brevíssimo aproveitamento da Teoria da Relatividade Geral, por excêntricas que tais correlações pareçam à primeira vista).

8 Além do que foi dito, na concepção peirciana, os símbolos, necessariamente, implicam índices e ícones, pois os fatores de Terceiridade requerem os de Secundidade e Primeiridade. (Há uma discussão densa de tal questão em Santaella (1995), p. 140-179, mais especialmente p. 171-179, sobre o símbolo.) 


\section{Agora, a Física Quântica}

Busquemos aqui sintetizar as (reconhecidas) estranhezas de Mecânica Quântica - lembrando que a maior parte do resumo abaixo diz respeito à Escola ou Interpretação de Copenhague, associada ao dinamarquês Niels Bohr:

1) A energia se propaga em "pacotes" discretos, descontínuos, chamados por Max Planck de quanta (plural do latim quantum: "quantidade"): em 1900, ele descobriu que os elétrons emitem ou absorvem energia somente em determinadas quantidades, mensuráveis como descontínuas, que o célebre cientista considerou quanta de energia. A energia é um caso específico da menor quantidade possível, da mais ínfima porção de uma grandeza física que se pode medir quando se atenta para os valores prováveis de tal grandeza. Lidando com a radiação eletromagnética, no contexto do problema do "corpo negro", Planck derivou a fórmula $\mathbf{E}=\mathbf{h f}$, na qual $\mathbf{h}$ é uma constante universal (ou constante de Planck) e f, a frequência de radiação expedida (OLIVEIRA, 2010, p. 79-83). A constante h é um número minúsculo, que foi a base da imensa revolução que a Mecânica Quântica provocou (e segue provocando) na nossa compreensão do que seja o real.

2) A luz (fótons) e a matéria (elétrons, etc.) apresentam uma natureza dupla: ora comportam-se como ondas, ora como partículas ou corpúsculos - e esta dualidade não é característica do que passou a considerar-se a dimensão costumeira, clássica, newtoniana da realidade (vale dizer, pré-quântica: na nossa percepção habitual, as partículas se localizam pontualmente no universo, como grãos de areia, ao passo que as ondas em geral se espalham pelo ambiente, com fronteiras pouco nítidas, sem muita clareza do que sejam os 
seus começos e os seus fins ${ }^{9}$ ). Tal dualismo é evidenciado em experiências como a da dupla fenda, primeiro efetuada por Thomas Young em 1801, para a luminosidade (e apenas o caráter ondulatório desta foi inferido pelo versátil cientista inglês). Assim Paul G. Hewitt descreve o caso da luz, no experimento de dupla fenda: "Um fóton se comporta como uma partícula quando está sendo emitido por um átomo, ou absorvido por um filme fotográfico ou outros detectores, e comporta-se como uma onda quando está se propagando da fonte para o local detectado" (HEWITT, 2011, p. 560). 0 caso da matéria (representada pelo elétron) é o seguinte: "Como os fótons, os elétrons incidem na tela [detectora] como partículas, mas o padrão de chegada é de natureza ondulatória" (HEWITT, 2011, p. 561). Para o estabelecimento histórico da dualidade aludida foi fundamental a hipótese, lançada por Albert Einstein em 1905, de que, ao propagar-se, a luz comporta-se como se feita por partículas (denominadas fótons por Gilbert S. Lewis em 1926), no âmbito da sua discussão do "efeito fotoelétrico", ao qual aplicou a ideia de quantização de Planck. A consideração corpuscular einsteiniana foi comprovada de modo experimental em 1916, por Robert A. Millikan, após anos de testes. Tal consideração passou a conviver com a visão ondulatória do eletromagnetismo oriunda do século XIX, contrariando a concepção de que a luz se portava apenas como onda. No que concerne à matéria, foi proposta em 1923, numa ousada tese de doutorado de Louis de Broglie, inspirado no trabalho de Einstein, a conjectura de que as partículas

9 “Um corpúsculo clássico tem energia e momento linear [quantidade de movimento] concentrados em região puntiforme e estas grandezas se propagam assim concentradas. [...] As ondas clássicas se espalham e se expandem, a energia e o momento das ondas preenchem o espaço, não são localizadas. [...] Os corpúsculos atômicos têm energia e momento concentrados em região puntiforme, mas apresentam propriedades ondulatórias na experiência de Young" (LOPES, 2005, p. 499-450). 
materiais também se comportariam ondulatoriamente, o que se confirmou em 1927, quando Clinton Davisson, Lester Germer e George P. Thomson provaram que elétrons (corpúsculos de matéria) podem sofrer difração, típico aspecto das ondas (FEYNMAN, 2012, p. 134). Frisemos que nem as ondas nem as partículas da Física Quântica, entretanto, revelam semelhança completa com as partículas e as ondas que somos capazes de visualizar ou conceber no nosso cotidiano - embora a existência deste dependa do comportamento daquelas primeiras! (Entre o insight de Einstein e o de Louis de Broglie haveria o de Niels Bohr, em 1913, com a ideia do "salto quântico", quando da apresentação do seu modelo do átomo, que dava seguimento à descoberta do seu núcleo, por Ernest Rutherford, em 1911. Tal "salto" espantoso é resumido do modo subsequente: uma passagem descontínua, efetuada por um elétron, de uma órbita do átomo para outra, sem que ele percorra a distância entre as órbitas! Devido a "saltos" do tipo, e com a evolução da teoria quântica, que se fez probabilística, as "órbitas" dos elétrons não mais corresponderiam a um modelo "planetário" como o de 1911, pois elas - que sequer poderiam ser descritas como tal, merecendo aspas - equivaleriam apenas aos valores mais prováveis permitidos pela função de onda, ou, falando com maior precisão, ao quadrado desta: cf. mais abaixo os itens 4, 7, 9 e 10, em especial).

3) Quando observada (medida), uma onda quântica passa a comportar-se, subitamente, como partícula, o que, no jargão dos físicos, se denomina "colapso da função de onda" ou "redução de estado". Eis outro modo (levemente imagético, icônico) de descrever isto: "uma onda de probabilidade [...] muda de uma forma bem distribuída para uma forma pontiaguda" (GREENE, 2005, p. 622, grifo nosso).

4) A "função de onda" da matéria (ou "psi": $\psi$ ) obede- 
ce ao formalismo matemático da equação (diferencial) de Erwin Schrödinger (em homenagem ao físico austríaco que a descobriu, em 1926), dando origem à Mecânica Ondulatória dos quanta, que se revelou compatível com outra versão dos mesmos, a Mecânica Matricial de Werner Heisenberg, postulada já em 1925. Neste par de anos, aliás, como lembra Richard Feynman, foram descobertas as "equações corretas da Mecânica Quântica” (FEYNMAN, 2012, p. 134), claro que sem desconsideração do que se conquistara antes nem do que se obteria depois de tal biênio.

5) Segundo o formalismo citado, um sistema físico quântico evolui de maneira "unitária”, ou seja, "contínua, linear, determinista e reversível" (PESSOA Jr., 2006, p. 45). Kleber Daum Machado refere-se às ondas de matéria como "finitas, contínuas e unívocas", portando "toda a informação física que possa ser necessária” (MACHADO, 1999, p. 419, grifo nosso; cf. também EISBERG; RESNICK, 1979, p. 183).

6) A alínea anterior alude à noção de continuidade, cara a Peirce, que, na sua filosofia, a chamava de sinequismo; todavia, a descontinuidade também se acha implicada no quantum, tal como descoberto por Planck: descontinuidade da qual chegaremos mais perto no item 8 .

7) As ondas da equação de Schrödinger por igual são denominadas "pacotes de ondas", portando amplitude (que "mede o desvio de sua variável física em relação ao estado de repouso", conforme Herbert, 1989, p. 95). Se carrega mais amplitude, um pacote de ondas apresenta maior valor estatístico em certas extensões do espaço do que em outras, logo espalhando-se com celeridade: entregue a si mesmo (não medido), um quantum revela a incrível característica de, em pouquíssimo tempo, estar em vários locais de uma cidade, com probabilidades diferentes (aqui menor, maior ali, média 
adiante, etc.); conceda-lhe mais tempo e ele "poderá aparecer em qualquer lugar do país, até mesmo de toda a galáxia" (GOSWAMI, 2010, p. 60).

8) Tal continuidade inusitada, porém, não anula a implicação radical da descontinuidade descoberta por Planck, como esta não elimina o caráter de continuidade (linearidade, determinismo, reversibilidade) da onda de matéria, graças à dualidade onda-partícula. A equação de Schrödinger evidencia uma das duas faces da microfísica: o aspecto ondulatório liga-se à ideia de continuidade. Efetue-se, entretanto, a observação (medição) de uma onda de matéria: meça-se, por exemplo, a "carga do elétron", experiência em que ele será interceptado numa câmara de condensação por alguma nuvem de vapor; ocorrerá então o colapso da função de onda, quando esta como que se estreitará num ponto, numa localização precisa, o que, afinal, introduz a descontinuidade no seio da continuidade, de modo repentino, tanto mais surpreendente quanto o colapso (ou maior "definição" da matéria, não mais o seu espalhamento numa "nuvem de probabilidade", por uma cidade ou uma galáxia) não é previsto pela própria equação de Schrödinger!

9) Para acentuar a esquisitice do que vamos afirmando (e que os cientistas denominam contraintuitivo, "não pictórico" ou não visualizável pela nossa mente), frisemos que as ondas de matéria são, de fato, como notado por Max Born já em 1926, "ondas de possibilidade", não objetos físicos! Quando demonstra um comportamento ondulatório, a matéria é "simples" conjunto de possibilidades, vale dizer, superposição ou coexistência de estados ou localizações, algo ainda não propriamente físico, "apenas" informação, que se acha não no nosso espaço-tempo quadridimensional (einsteiniano), mas num com mais dimensões, dito "espaço de Hilbert" 
(que o descobrira fazia muitos anos, sem poder imaginar que, no futuro, ele seria apropriado para a Física Quântica!).

10) A interpretação da função de onda $\psi$, por Max Born, baseia-se no seguinte: tanto as ondas comuns do nosso cotidiano (aquáticas, sonoras, etc.) quanto as de micromatéria possuem a amplitude a que nos referimos no item 7. Ambas as espécies de ondas podem ter também as suas intensidades mensuradas, com a elevação da amplitude ao quadrado. Aqui, porém, algo inusitado irá perceber-se: "Para todas as ondas, exceto as quânticas, a intensidade dá a medida da quantidade de energia transportada pela onda em cada ponto. As ondas quânticas não transportam energia alguma [...]. A intensidade (amplitude elevada ao quadrado) da onda quântica é uma medida de probabilidade" (HERBERT, 1989, p. 95, grifo nosso). Reiterando: "Para uma onda quântica, o quadrado da sua amplitude (no local $\mathbf{x}$ ) representa não energia, mas a probabilidade de que uma partícula - um pacote de energia localizada - será observada caso um detector esteja posicionado no local x" (HERBERT, 1989, p. 122). 0 físico norte-americano que citamos adverte: $\psi$ (ou função de onda pura e simplesmente) é uma onda de possibilidade, ao passo que $\psi$ elevada ao quadrado é uma onda de probabilidade, "sendo a possibilidade, de algum modo, menos real do que a probabilidade. [...] A amplitude de uma onda quântica é a sua possibilidade. 0 quadrado de uma possibilidade é uma probabilidade" (HERBERT, 1989, p. 122) ${ }^{10}$.

11) A utilização do espaço hilbertiano na Física Quântica consolidou-se com John von Neumann. Em 1932, ele publi-

10 Sem distinguir entre "possibilidade" e "probabilidade", Richard Feynman também assinala que a amplitude de uma onda quântica traz informação diversa da de uma onda comum: "Ela [amplitude] descreve o quê? Não a energia de uma onda, mas a probabilidade de chegada dessas unidades [elétrons, no caso]" (FEYNMAN, 2012, p. 143, grifo nosso). 
cou Fundamentos matemáticos da Mecânica Quântica. 0 seu trabalho acabou "colocando a teoria quântica num elegante edifício matemático denominado 'espaço de Hilbert'” (HERBERT, 1989, p. 41-42) ${ }^{11}$.

12) Quer o formalismo matemático da Física Quântica, quer as experiências que a testam parecem dar razão ao que escreveu Ivan S. Oliveira: “[...] objetos [...] como elétrons, prótons e átomos não têm um lugar definido no espaço. De fato, é necessário supor que esses objetos não tenham a propriedade de 'estar em algum lugar', a menos que se faça um experimento para se observar sua posição". E mais: "0 mesmo acontece com [...] propriedades físicas [...] como a energia e a velocidade. Segundo a Mecânica Quântica, não tem sentido físico [...] imaginar que um elétron [...] 'esteja em algum lugar' bem definido, nem mesmo tenha certa energia e velocidade $[\ldots]^{\prime \prime 12}$.

13) Mesmo com a oposição obstinada de Einstein, os cientistas da microfísica precisaram admitir que, ao menos no seu nível mais fundamental, a natureza atua de modo probabilista, já não de acordo com a causalidade clássica, herdada do desenvolvimento da física newtoniana ${ }^{13}$. Junte-se a isto o Princípio da Incerteza ou Indeterminação, apresentado por Werner Heisenberg em 1927 (que discutiremos na quinta se-

11 Uma clara apresentação do "espaço de Hilbert", tal como utilizado no formalismo quântico, pode ser encontrada em Penrose (1991, p. 284-292).

12 Disponível em http://cienciahoje.uol.com.br/revista-ch/2011/282/revisitando-a-estranha-natureza-da-realidade-quantica. Acesso em 06 set. 2011.

13 A física clássica, sobretudo com a contribuição laplaciana, também pode lidar com probabilidades, mas, em casos de moedas, dados jogados, etc., isto será "somente uma maneira de quantificarmos a nossa ignorância”, ao passo que, em Mecânica Quântica, o probabilismo, "com a interpretação de Born, é intrínseco ao problema" (OLIVEIRA, 2010, p. 91). Ou, nas palavras de outros físicos, "de longe mais fundamental foi a descoberta de que, na natureza, as leis de combinação de probabilidades não eram as da teoria da probabilidade clássica de Laplace" (FEYNMAN; HIBBS, 2010, p. 2, tradução nossa). 
ção do nosso trabalho). Por sua vez, a tal Princípio se associa outro, de Niels Bohr, chamado da Complementaridade, que se sintetiza assim: "Um fenômeno não pode ser ao mesmo tempo ondulatório e corpuscular" (PESSOA Jr., 2006, p. 31, grifo nosso). Ou numa das formulações do seu criador: “[...] os dados obtidos em diferentes condições experimentais não podem ser compreendidos dentro de um quadro único, mas devem ser considerados complementares, no sentido de que só a totalidade dos fenômenos esgota as informações possíveis sobre os objetos" (BOHR, 2008, p. 51).

14) Claro que necessitamos conciliar os aspectos mais esdrúxulos da realidade quântica com os que vivemos em nosso cotidiano, muito bem descrito pela Física Clássica newtoniana. Um dos recursos utilizados para tanto é o Princípio da Correspondência, também de Niels Bohr. Eis como o resume Ramayana Gazzinelli: "[...] há um limite na observação dos sistemas microscópicos (quando são muito grandes, ou quando a constante de Planck se torna desprezível), em que as respostas dadas pela Física Quântica devem concordar com as da física clássica" (GAZZINELLI, 2013, p. 134).

15) Talvez agora a "mãe de todas as estranhezas" herdadas da lógica que aprendemos com a Escola de Copenhague. Descrevamo-la de feição simplificada. Uma vez postas em contato, em inter-relação, duas partículas, depois afastadas (não importando a distância entre elas), continuam a relacionar-se em certos aspectos: meça-se apenas uma e a outra irá reagir, ao que tudo indica, de imediato (o que se vincula à noção de não-localidade, ou de conexões para além de contextos localmente conectados - ou conectados nos limites da velocidade da luz)! Desde 1935, graças a Einstein, Boris Podolsky e Nathan Rosen e, ainda, Schrödinger, isto é visto como emaranhamento quântico (também passível de ocorrer em con- 
textos locais, ou de conexão clássica: cf. ALMEIDA, 2010, p. 53-59) - algo que se vem confirmando dos anos 1970 para cá, principalmente a partir de 1982, com a experiência mais decisiva de Alan Aspect e sua equipe, que puseram o fenômeno à prova, corroborando-o. Não à toa, Einstein, incrédulo, referiase a tal ocorrência como "ação fantasmagórica à distância" (cf. GAZZINELLI, 2013, p. 113-124).

16) Não se deixe sem referência que, no fim dos anos 1960, o cientista Hans Dieter Zeh passou a analisar a possibilidade de o próprio meio ambiente provocar os colapsos das funções de onda. Isto veio a ser conhecido como decoerência, a qual anularia a coerência do mundo quântico (os bizarros fenômenos que temos descrito, ligados em geral ao caráter ondulatório da matéria e da luz), tornando-o o clássico em que vivemos cotidianamente. A decoerência obteve aceitação na comunidade dos físicos, após o ostracismo a que foi condenada pelos herdeiros da Escola ou Interpretação de Copenhague (cf. BÄCHOLD, 2008, p. 78-85, FREIRE Jr. in: FREIRE Jr. et al., 2010, p. 36-40 e PATY, 2009, p. 86-90).

\section{Um peirciano-quantismo, por assim dizer}

Podemos agora, finalmente, explicitar a nossa proposta do que chamamos realismo semiótico peirciano para uma das versões da Física Quântica (MACHADO, 2013, passim). Não esqueçamos: na fase mais avançada do seu pensamento, Peirce concedeu foros de realidade às suas três categorias, não apenas à Secundidade. E ele também ousara colocar em questão "a doutrina da regra perfeita da causalidade" como explicação para os fenômenos da natureza:

[...] muitas pessoas terão uma dificuldade em conceber um elemento sem lei no universo, e [...] podem [...] ser tentadas a 
considerar a doutrina da regra perfeita da causalidade como uma das crenças instintivas originais [...]. Longe disto, ela é uma noção [...] moderna [...]. Aristóteles [...] afirma que algumas coisas são determinadas por causas enquanto outras ocorrem por acaso. Lucrécio, seguindo Demócrito, supõe que seus átomos primordiais desviam-se de trajetórias retilíneas de modo fortuito [...] (PEIRCE apud IBRI, 1992, p. 44; $C P, 1.403)$.

Frisemos, todavia, que o nosso paralelo entre o autor norte-americano e a Mecânica Quântica não é intentado com a expectativa de que ele revele correspondências integrais ou ponto a ponto.

Trazendo o raciocínio do filósofo para o domínio que Planck começou a descobrir, aventamos o seguinte: a) a Primeiridade (Acaso, indeterminismo) encontra correspondência razoável na esfera das funções de onda ou ondas de possibilidade (que, tendo as suas amplitudes elevadas ao quadrado, se tornam ondas de probabilidade), associadas ao espaço de Hilbert; b) a Secundidade (Existência, "aqui e agora"), no campo das partículas detectadas; c) a Terceiridade (Lei, abrangência), no terreno das regras que regem as Físicas Quântica e Clássica: o âmbito das generalidades, na categoria que, de acordo com o pensador, é o modo máximo de manifestação da realidade, mais do que mera construção intelectualizada de seres como os humanos. Do ponto de vista da reflexão triádica, o cérebro, com os seus tecidos, neurônios, etc., é real (Secundidade); também o é o pensamento (Terceiridade). A defesa da sua realidade não significa que tudo o que ele venha a conjecturar será "verdadeiro", "evidente", "natural"... Por quê? Devido a nossa tendência ao que Peirce chamava falibilismo, ligado ao tiquismo universal, com a sua tessitura "de incerteza e indeterminação" (PEIRCE, 
$C P, 1.171)$, na qual nos encontramos imersos. Decerto, até ao errarmos absurdamente, estamos atuando em concordância com o tecido (triádico) do real, que carrega a possibilidade de desacerto no seu âmago.

Reforça a nossa proposição a lembrança de que, nos anos 1950, em Física e filosofia, Werner Heisenberg retomou a noção aristotélica de potencialidade (dýnamis-potentia), para redefinir a função de onda de Schrödinger (cf. HEISENBERG, 1999, p. 61, 78, 81, 206 e 222). Recordemos que Adriano Duarte Rodrigues relacionou a Primeiridade "com aquilo a que Aristóteles e os escolásticos davam o nome de potência" (RODRIGUES, 1991, p. 86).

Intensifica-se o nosso paralelo ainda mais com a seguinte informação: “[...] a função de onda $\psi$ [...] é uma grandeza não observável (não pode ser medida); no entanto o quadrado de $\psi$ é observável e está relacionado à probabilidade de um evento" (GAZZINELLI, 2013, p. 134, grifo nosso). Juntemse as palavras do físico ao cotejo que empreendemos. Resultado: a Mecânica Quântica transforma a Primeiridade de Peirce em algo observável no que se refere ao quadrado da amplitude, o que, por outro lado, não é pouco, pois daí é que se chegará ao "evento", ou seja, à Secundidade!

Acreditamos que a proposição de um cotejo peircianoquântico, como o sugerido, é a de um realismo multifacetado, que associa a filosofia do nosso autor à Mecânica dos quanta, de acordo com a Interpretação de Copenhague, enriquecida com a noção da decoerência. Uma trirrealismo - ou versão triádica realista da Física Quântica. Eis o quadro geral em que irão inserir-se mais propostas deste artigo, a seguir 
desenvolvidas ${ }^{14}$.

De acordo com a lógica do trirrealismo que sustentamos, a própria dualidade onda-partícula é, na verdade, um triadismo onda-partícula-tipo de medição, quer a dos homens, quer a do restante da natureza (decoerência). 0 mesmo raciocínio vale para a Complementaridade de Niels Bohr: se um fenômeno não pode ser, conjuntamente, ondulatório (A) e corpuscular (B), tal Princípio nos coloca numa posição (C), ou seja, numa condição de Terceiridade (estranha, admitimos), perante o dualismo quântico em foco. A dualidade dos quanta e a Complementaridade bohriana que dela procura dar conta desembocam, portanto, num triadismo semiótico, vale dizer, exigem a ação de um interpretante (seres sencientes ou a natureza restante). Dependendo da escolha do aparato experimental usado na observação, um quantum irá apresentar-se como onda ou partícula, isto é, o seu comportamento dependerá da opção pelo interpretante imediato ondulatório ou o corpuscular, implicado no aparato da experiência a ser feita. Na versão oriunda de Copenhague, analisada semioticamente, tal interpretante, transformando-se em dinâmico, veio a ter como um dos seus nomes "colapso da função de onda", mesmo não ficando bem claro o motivo de ele ocorrer (o que nos daria um interpretante final)!

Aproximamo-nos acima do triângulo semiótico. Teremos o (1) signo denominado quantum, o (2) objeto dinâmico ondulatório (2.1) em certos experimentos e corpuscular (2.2) em outros e o (3) interpretante dinâmico complemen-

$14 \mathrm{O}$ fato de o realismo de Peirce ser semiótico invalida qualquer caracterização sua como "ingênuo", "positivista", "essencialista", etc. Trata-se de um realismo que depende quer das categorias de Primeiridade, Secundidade e Terceiridade, quer das vinculações entre signo, objeto e interpretante, não privilegiando nenhuma destas três últimas noções em prejuízo das demais. Um realismo (ontológico) de mediações (semióticas), não de crença numa relação "imediata" com o mundo. 
tar (ou bohriano). A natureza dualista do objeto acarretará que, também em termos sígnicos, ele revele dupla face: uma icônica, outra indicial (como discutiremos abaixo, na quarta e na quinta seções do nosso trabalho).

\section{0 Princípio da Incerteza ou Indeterminação numa perspectiva sígnica triádica}

Recordemos a definição do filósofo: a Secundidade subentende dois elementos em contato, experiências diádicas, recorrências, pares de objetos em conexão.

Pois bem: o Princípio da Incerteza ou Indeterminação, formulado em 1927 por Werner Heisenberg (Terceiridade), traz ao foco um nível indicial da realidade que não é o da mecânica clássica (newtoniana e einsteiniana). Já matematicamente, ele estabelece que, ao obtermos de modo mais preciso a posição de uma partícula, perdemos a precisão no que diz respeito ao seu momentum (quantidade de movimento), qualquer que seja o aparato de medição utilizado. Este Princípio aplicase a todas as outras grandezas conjugadas (ou pares de observáveis) do âmbito quântico, como tempo e energia: de acordo com o que ele enuncia, jamais seríamos capazes de precisar, em simultâneo, o valor de tais grandezas em jogo. Ora, uma tal situação é indicial, envolvendo contiguidade, já que interferimos no mundo atômico e subatômico ao lidarmos com ele. Enfatizemos que se trata, todavia, de uma indicialidade diferente da clássica, uma conexão inusitada, pois, em termos físicos, sujeito (medidor) e objeto (medido) não são agora entidades separáveis: o segundo se liga intimamente ao primeiro, formando uma díade estranha, pouco nítida, no processo (mas que segue sendo uma díade). Trata-se, ainda, de uma condição imposta pela própria natureza, não por veleidade nossa de 
interferir nela. 0 físico Antonio S. T. Pires descreve assim a situação descoberta por Heisenberg: "Em um sentido [...] amplo, a razão pela qual não podemos medir posição e velocidade ao mesmo tempo com uma precisão arbitrária é porque o conceito de posição e [o de] velocidade não existem ao mesmo tempo" (PIRES, 2012, p. 43).

Cremos que, se Peirce pudera conhecer esse fato regido pela lei e pela correspondente relação matemática que Heisenberg descobriu (generalizável como Terceiridade), teria imaginado uma nova indicialidade, uma Secundidade inédita atuando ali. Enfoque-se A (posição) de modo mais preciso; consequentemente, perca-se a precisão de B (momentum) e vice-versa. Num caso, o foco em A afeta B; no outro, a focalização em B perturba A. (Pode-se imaginar mais "dinâmica conexão" ou maior indicialidade do que esta?)

O Princípio da Indeterminação de Heisenberg é um fator triádico (pois geral) explicativo de um evento diádico desconcertante: uma interferência física inevitável do medidor (não por sua vontade, insistamos, mas por restrição imposta pela natureza) no objeto que ele vai medindo, a qual institui um limite para o conhecimento mais rigoroso desse objeto (fazendo-o transitar da esfera da potencialidade para a do objeto dinâmico atômico ou subatômico, sem exatidão completa).

Microscópica, a indicialidade do mundo quântico impõe que este de imediato reaja à presença perscrutadora do observador macroscópico, estabelecendo com ele uma conexão que envolve interferência, regida pelo Princípio da Indeterminação. Aqui, não há observação (medição) de um fator ou aspecto da potencialidade denominada quantum sem consequente transformação de outro aspecto da mesma potencialidade, àquele conjugado.

Triadismo (o Princípio referido), diadismo (a medi- 
ção)... Onde se localiza o fator monádico ou a Primeiridade peirciano-quântica, se ela existe, no processo?

A onda de possibilidade é um ícone quântico, já que, de acordo com o tratamento (matemático e interpretativo) a que a submeteu Max Born, carrega a probabilidade de que uma partícula seja detectável aqui ou ali ${ }^{15}$. Ela comporta informação sobre o elemento atômico ou subatômico, vale dizer, é um signo estatístico, potencial, embora não "especular", não "pictórico", desse objeto. Só quando ela for medida, ou sofrer decoerência induzida pelo meio-ambiente, localizarse-á na Secundidade, como partícula. Tudo leva a crer que a medição e a decoerência são, por conseguinte, fatores de Secundidade que perturbam algo potencialmente associado à Primeiridade.

Retomemos o filósofo: Primeiridade é a categoria que concerne às experiências monádicas, sensações e qualidades - completas em si mesmas, não relacionadas ainda a outros fenômenos. Notemos: "não relacionadas ainda a outros fenômenos", isto é, como que ainda não medidas... E ainda: "Uma simples possibilidade é um Ícone puramente por força de sua qualidade, e seu objeto só pode ser uma Primeiridade" (PEIRCE, 1977, p. 64; CP, 2.276). "Possibilidade" que, na esfera dos quanta, deixaria de ser "simples", pois, elevada matematicamente ao quadrado, torna-se "probabilidade", ainda um predicado da Firstness.

Supomos que o "espaço de Hilbert" é a arena icônica em que, matemática e também realisticamente, as ondas se

15 Pensar aspectos especializados da physis como semiosis não é algo forçado no terreno peirciano. Num dos parágrafos do próprio filósofo, em que ele discorre sobre "A natureza dos símbolos", aparece a inesperada afirmativa: "Toda força atua entre um par de partículas, uma qualquer das quais pode servir como um índice da outra" (PEIRCE, 1977, p. 73; CP II, 2.300, grifo nosso). Decerto, Peirce devia ter em mente a Física Clássica (Gravitação Universal Newtoniana, Lei de Coulomb, Eletromagnetismo). E a força - qualquer que esta seja aqui - seria um fator de Terceiridade, envolvendo a díade de partículas. 
desenvolvem. Por consequência, após o colapso ou a decoerência da sua onda de matéria, cada partícula deverá ser um índice do que a onda foi ou uma das suas possibilidades concretizada (ou colapsada).

Há uma modalidade de evento em que não apenas a Primeiridade como por igual a Secundidade se efetuam ambas de modo quântico, claro que num processo mediado por uma Lei ou Terceiridade.

Logo que se encontram no nosso dia-a-dia clássico, duas ondas comuns (não quânticas: acústicas, aquáticas, etc.), que existem de maneira evidente aos nossos órgãos sensoriais, sobrepõem-se, produzindo o fenômeno de interferência. Coincidindo as cristas e os vales das ondas, teremos uma interferência construtiva, indicando que as ondas estão em fase. Não havendo essa coincidência de vales e cristas, teremos uma interferência destrutiva, significando que elas estão fora de fase. Interessante que, também no mundo quântico, duas ondas de possibilidade interagem positiva ou negativamente. Que "coisas" interagem aqui, todavia? Potencialidades, ainda não concretudes. Esta sobreposição é uma ocorrência de indicialidade (Secundidade), incidindo em dois ícones ondulatórios (Primeiridade), imateriais, todavia reais, numa visão peirciana - pouco ortodoxa agora tal visão, reconheçamos, pois conduz a lógica da categoria de Secundidade para um domínio de Primeiridade (ondas de matéria) que o filósofo não podia antecipar... Por outro lado, isto parece consistente com o quantismo, no que a sua dimensão ondulatória própria ainda revela ter de comum com a da Física Clássica. Diz Osvaldo Pessoa Jr (2006, p. 6):

[...] muitos dos mistérios da Física Quântica [...] são fenômenos descritos na Física Ondulatória Clássica, e que passam a ser fenômenos quânticos quando se reduz a intensidade do 
feixe [de partículas] e se melhora a sensibilidade dos detectores [das mesmas].

[...] Um exemplo disso é a diferença que existe, para as ondas clássicas [e as quânticas], entre amplitude e intensidade.

Categoricamente falando, as "ondas clássicas" são o que denominaríamos "ondas de Secundidade"; às "ondas quânticas" (com amplitudes elevadas ou não ao quadrado) chamaríamos "ondas de Primeiridade". Ambas as espécies compartilham, portanto, certos traços, como as interferências construtivas e as destrutivas - e estas, em visão peirciana, são exemplos (inesperados, quando pressupostos na esfera dos quanta) de indicialidade ${ }^{16}$.

\section{A ação sígnica no coração (quântico) da natureza conhecida}

Numa visada peirciana, o panorama com que findamos a seção anterior é real, ainda que o filósofo norte-americano não tivesse condições históricas para adivinhar as estranhezas do quantismo. Sem dúvida, os termos forjados por Peirce às vezes são de surpreender, mas nos ajudam a assimilar o que há de contraintuitivo no terreno do quantum, que regula o comportamento íntimo da matéria conhecida do universo: cerca de meros quatro por cento da sua totalidade, sendo a única com a qual, por ora, interagimos.

Argumentamos que a onda de possibilidade é um ícone quântico, pois, elevada ao quadrado, carrega a probabilidade de que uma partícula seja detectada acolá ou aqui. Ela por-

16 "A Mecânica Clássica pode ser deduzida da Mecânica Quântica, mas o oposto não é verdadeiro" (SAKURAI; NAPOLITANO, 2011, p. 84, tradução nossa): portanto, se ambas compartem certos aspectos, nem por isto a primeira deixa de ser um caso da segunda. 
ta informação sobre os elementos atômicos e subatômicos, sendo um representante estatístico destes mesmos objetos. Falamos também do aspecto indicial da partícula. Agora, retomemos estes pormenores, ampliando-os.

Registremos a partícula macroscopicamente (ao fim de um experimento como o de Stern-Gerlach ou numa chapa fotográfica no experimento de dupla fenda), após o colapso da onda de matéria: ela será um índice do que foi a onda. Isto não é jogo forçado de ideias: caso os minúsculos componentes do mundo material fossem tão só partículas, não precisaríamos supor que eles também já são signos. A motivação para isto resulta de uma dupla descoberta da Mecânica Quântica: após a hipótese de Einstein do caráter corpuscular da luz, começou-se aos poucos a ver que havia uma dualidade onda-partícula para a mesma luz; aventou mais tarde, com acerto, Louis de Broglie, também existir uma dualidade onda-partícula para a matéria. Uma díade surpreendente: a onda é uma face (potencial, de amplitude maior ou menor) da partícula; por sua vez, esta é uma face (restrita, colapsada) da onda. Cada uma é signo da outra, numa semiose complementar, raciocinando em termos de Niels Bohr. Ou onda (podendo ser partícula), ou partícula (com alguma indicação do que foi a onda)... Diante de tal situação, que sempre parece apresentar-se de modo exclusivo, quer o meio-ambiente quer o observador (uma parcela do meio-ambiente, afinal ${ }^{17}$ ) interferem nos fenômenos quânticos, situados todos numa realidade cósmica maior, acompanhada de uma Terceiridade que deve explicar porque as coisas ocorrem assim.

Na verdade, as experiências de detecção de fótons (luz)

17 “[...] pessoas ([...], diga-se de passagem, são também fenômenos da Natureza!)" (OLIVEIRA, 2010, p. 112). Dadas as estranhezas da Mecânica Quântica, é prudente mantermos isto sempre em vista... 
e elétrons (matéria) se revelam mais sutis do que a maneira como foram descritas acima dá a entender, sem que invalidem o nosso raciocínio: por exemplo, no experimento de dupla fenda, os quanta são detectados pontualmente, em forma de partículas (indicialidade); se forem escassas as detecções, os padrões ondulatórios (iconicidade) não se farão perceptíveis; aumente-se a emissão dos quanta (de poucas dezenas até milhares) e tais padrões aparecerão, mostrando os efeitos do fator "corpúsculo" e do fator "onda" da matéria e da luz. Dizemos efeitos porque "ondas de matéria, como as ondas luminosas, são ondas de probabilidade" (HALLIDAY; RESNICK, 2012, p. 189). Avisa Nick Herbert: "Por não transportar energia [como uma onda clássica], a onda quântica não pode ser observada diretamente; nunca vemos uma onda quântica, vemos apenas as partículas quânticas" (HERBERT, 1989, p. 122 , grifo nosso). Isto equivale a dizer: sim, de jeito imediato, não enxergamos a onda de um quantum (não se veem possibilidades!), mas, se olharmos o registro de muitos quanta num experimento adequado, "damos de cara" com o padrão de interferência (ou as "franjas de interferência"), típico da propriedade ondulatória luminosa e da material (percebível, pois, de jeito mediato, característico da semiose). Aqui, os índices pontualmente detectados (Secundidade) ajudam-nos a inferir a iconicidade probabilística (Primeiridade), implicada na dualidade onda-partícula. Para tentar tornar claro (intuitivo) o que é estranho (contraintuitivo) por natureza, outra vez nos socorramos de Antonio S. T. Pires:

[...] consideremos uma partícula se movendo ao longo de uma reta entre dois pontos. [...] A partir da solução da equação de Schrödinger, e usando o postulado de Born, podemos encontrar, por exemplo, que a probabilidade de encontrar a partícula, caso uma medição seja feita, próxima de um ponto 
P é de 1/4. Isso quer dizer que se temos mil conjuntos idênti$\cos$ ao que foi descrito e fazemos medidas nesses sistemas, vamos encontrar a partícula próxima de $\mathbf{P}$ em cerca de 250 sistemas (PIRES, 2012, p. 32).

Em termos semióticos, a fração probabilística 1/4, obtida por meio da equação de onda e do postulado de Born, é o que chamamos ícone quântico (de base matemática, estatística), ao passo que os cerca de 250 resultados, conseguidos por medições nos "mil conjuntos idênticos" citados acima, são os índices que também postulamos - como o seriam, se constatássemos pouco mais ou menos de 2500 resultados, em dez mil "conjuntos [ainda] idênticos". A fração $1 / 4$ manteria a sua iconicidade. A similaridade ondulatória implicada na situação seguiria sendo praticamente a mesma. Probabilidade de perto de $1 / 4,1 / 4,1 / 4 \ldots \mathbf{n}$ vezes.

Pensemos na concepção triádica mais econômica da semiose: a que afirma estar o signo no lugar de algo (por semelhança, contiguidade ou imputação decorrente do hábito) para alguma inteligência. Esta noção se "traduz" dos dois modos subsequentes, no que concerne à dualidade onda-partícula: 1) ondas de matéria são signos icônicos que representam as características ondulatórias das partículas, para quem prepare um experimento com interpretantes imediatos precisamente ondulatórios; 2) falando de jeito complementar, partículas são signos indiciais que representam as características corpusculares das ondas de matéria, para quem prepare um experimento com interpretantes imediatos precisamente corpusculares.

As duas "traduções" acima, complementarmente efetuadas, não nos parecem casuais, aplicações mais ou menos engenhosas da semiótica ao domínio dos quanta. Talvez alguma coisa decisiva se entremostre aqui. Por que se vai dos signos 
para a matéria atômica e subatômica dessa maneira aparentemente tão natural, uma vez que se mergulhe no mundo da semiose e na microfísica? Antes de darmos uma resposta a isto nos três parágrafos seguintes, admitamos que, com a presente linha de raciocínio, a distinção entre 1) o signo e 2) o objeto se obscurece: quer as ondas quer as partículas passem a comportar-se como aqueles dois fatores ("signo" e "objeto") do triângulo semiótico, ainda que de jeito complementar, tendo em vista 3) o interpretante filosófico (peirciano) e científico (quântico) que delas se obtém ${ }^{18}$. Sem dúvida; o próprio pensador, todavia, fez algo parecido com nada menos do que o universo, segundo já notaremos!

Peirce presumia que a semiose não está circunscrita ao domínio humano, mas ocorre normalmente no cosmo, o que equivale a dizer: questões envolvendo significância não são meras projeções humanas no real, ou jogos de linguagem antropomórficos, sequer se localizam tão só num âmbito de vastidão maior, como o da relação dos organismos com o meio ambiente.

A Física Quântica parece ser uma comprovação inesperada da concepção do filósofo. E também a Teoria da Relatividade Geral, consoante - por extensão - veremos.

Para a mente de um indivíduo que comece a conhecer a Mecânica Quântica, a dualidade onda-partícula da matéria (e da luz) é um signo duplo, um bissigno (digamos), ora ondulatório (Primeiridade), ora corpuscular (Secundidade): uma pessoa posta em tal situação de Terceiridade teórica deverá considerar que, sim, o próprio universo é sígnico, nas suas facetas material e luminar - de fato, um gerador infindável de signos, em meio a sua energia sempre constante. Esvazia-se outro, signos icônicos das partículas detectadas; estas são, por uma parte, objetos e, por outra, signos indiciais das ondas quânticas. Isto nunca em simultâneo. 
a possibilidade de qualquer interpretação apenas figurada (analógica, metafórica, alegórica, etc.) para a afirmativa literal de Peirce de que "Todo o Universo é penetrado por signos, se não se compõe até somente de signos" (apud NÖTH, 1999, p. 235; $C P, 5.448)$. 0 espaço-tempo einsteiniano igualmente? De novo, supomos que sim, se for verdade que, pela Teoria da Relatividade Geral e por medições efetuadas desde 1998, ele é a) deformado pela matéria que contém, ao passo que b) se expande a uma velocidade crescente, que ultrapassa a da luz. Sendo assim, então essa deformação - ou curvatura denominada gravitação - apresenta conexão indicial com as massas que a ocasionaram, do mesmo modo que acaba criando a geometria para as mesmas, igualmente em ligação indicial (Secundidade) ${ }^{19}$, além do pormenor de que algo misterioso vem provocando a velocidade superluminar referida (indicialidade outra vez, ainda que, por ora, de feitio obscuro). Caso tal aspecto da realidade não possuísse a natureza de índice, um sujeito chamado Einstein não conseguiria inferir o processo relativístico no seu fundamental, perdendo-se em meio a um aglomerado de coisas desconexas, jamais traduzíveis em termos de significações humanas - ou humanas porquanto triádicas: universais, que tratamos aqui como cósmicas (mais do que antrópicas ${ }^{20}$ ). Tais questões concernem fundo a nós, desejemos ou não.

19 "O espaço-tempo diz à matéria como ela deve se mover; a matéria diz ao espaço-tempo como ele deve se curvar" (CREASE, 2011, p. 163). Esta interpretação sintética é oriunda de John Wheeler.

20 Proposto por Robert Dicke em 1961 e Brandon Carter em 1972, o Princípio Antrópico é “o que diz que as constantes da natureza estão sintonizadas para permitir vida e inteligência" (KAKU, 2007, p. 236-237 e 362 para a definição). Por este Princípio (polêmico), a vida e a inteligência tornam-se muito especiais no cosmo. Alguns poucos cientistas chegaram a crer na figura de um Criador, sintonizando finamente tais constantes! Outros, com a noção de multiverso, acreditam que não precisamos de tal figura: num multicosmo, ao menos um universo estaria probabilisticamente sintonizado para gerar vida... 
Somos o quê? De muitos modos podemos responder a esta pergunta, um deles baseando-nos em algo que indiscutivelmente somos: matéria pensante, senciente, o mais que se queira, mas matéria. Encontramo-nos, por conseguinte, conectados às duas primeiras categorias acima. Falta a Terceiridade, mas ela sempre está por perto. Basta que nos indaguemos sobre o que significa um quantum, ou um buraco negro, ou o universo como um todo - e ei-la, em nível verbal, que pode transformar-se em teórico, etc. Atuamos como uma Terceiridade psicofísica, concretizada no que se denomina vida, que domina o planeta faz tempo (e que, de tempos em tempos, quase por completo experimenta a sua extinção). Deste modo, há mais do que chiste em anedotas de físicos tais como: somos um conglomerado de partículas de que as partículas lançam mão para indagar o que são as partículas... Dito de outro jeito: somos parcela do triadismo universal tomando consciência de si mesma e do próprio triadismo, numa região do cosmo. Vida inteligente: triadismo com chance de tornarse consciente de si (aumentar o seu teor de Terceiridade), precisamente enquanto fator "cosmotriádico".

\section{A semiose mais tipicamente humana em meio à semiose da matéria conhecida}

Neste momento, coloquemos a questão de saber se o que Peirce chama símbolo deixa-se interpretar tendo em mente a Física Moderna. Supomos que sim. Um símbolo, aqui: qualquer signo "cuja virtude está na generalidade de lei, regra, hábito ou convenção de que ele é portador e a função como signo dependerá precisamente dessa lei ou regra que determinará o seu interpretante" (SANTAELLA, 1995, p. 172).

Convenção, hábito ("adquirido ou nato"), regra e lei 
nunca são dados concretos, ao alcance da nossa mão (que, com essa gestualidade, pertence ao domínio da Secundidade, porção do real a que várias vezes reduzimos o real como um todo). Precisamos correlacionar tais fatores abstratizantes com a Física, dando-lhes o predicado de realidades, mesmo que não "objetais", no sentido da concretude.

Agora, concentremos nos símbolos de feição linguística, apenas.

Lembremos que o realismo peirciano-quântico aqui proposto implica três facetas: a) Primeiridade ou Potencialidades ou funções de onda; b) Secundidade ou Atualidades ou partículas após as detecções (medições) e eventos de decoerência; c) Terceiridade ou Leis estatísticas. Recordemos por igual que, na Física Quântica de acordo com a versão de Copenhague, o colapso da onda de matéria em partícula mais definida se dá de jeito descontínuo, descontinuidade de que fomos tomando ciência aos poucos, graças ao trabalho pioneiro de Max Planck, Einstein e Niels Bohr (este, com o célebre "salto quântico"). Em terminologia peirciano-quântica, o ícone de possibilidades-probabilidades chamado onda transforma-se num corpúsculo, por seu turno um índice do que foi a onda em causa, num acontecimento que se baseia não na causalidade clássica, mas num conjunto de potencialidades (em coerência quântica), de que será eleito este ou aquele aspecto, não todos os implicados em tal conjunto. Ocorrendo com regularidade, esta passagem do primeiro domínio para o segundo apenas pode ser concebida em termos de hábitos da natureza, estudados pela Mecânica dos quanta. A descontinuidade entre o ícone "onda" e o índice "partícula localizada", com o indeterminismo envolvido no processo, é o que dá margem à existência do fator simbólico. A feição mais convencional do símbolo vocabular (a que nos atemos no momento), a 
relativa liberdade de interpretação que lhe é inerente (e que a linguística de Saussure trata como arbitrariedade ou não motivação dos signos) procede indiretamente desse salto já descontínuo de um domínio (onda) para o outro (partícula), evento não visualizável pela mente humana, mas que ela é obrigada a reconhecer, desde os anos 1920. 0 caráter indireto de tal proveniência decorre, por sua vez, do fato de que a simbolização efetuada por seres vivos apenas pode acontecer, na prática, nos macrodomínios da Secundidade, não na esfera diminuta dos quanta (embora cada ano mais manipulável, por meio da nanotecnologia). Esclareçamos mais, por conseguinte, a nossa tese presente, pela seguinte formulação: no dia-adia, associamos um símbolo idiomático $\mathbf{x}$ (como o substantivo "faca") a um objeto $\mathbf{y}$, com o qual o signo $\mathbf{x}$, em princípio, não mantém qualquer relação (de semelhança ou conexão material), porque o universo em que vivemos funciona valendo-se da descontinuidade no reino atômico e subatômico. Ora, a junção de um símbolo verbal (ou signo saussuriano) a um objeto dinâmico (ainda que abstrato: não a "faca", mas o "desejo", digamos) é ela mesma uma ação mental que associa dois elementos (palavra e coisa) que não existem numa relação de continuidade, no cotidiano (reino "super" ou "macroatômico", se os termos forem aceitáveis). Parece-nos este um jeito razoável, mesmo que bastante trabalhoso, de correlacionar parcela do simbolismo do pensador norte-americano e a Física Quântica (onde há uma iconicidade ondulatória e uma indicialidade corpuscular, como defendemos).

Ora, aproximar a dimensão simbólico-linguística (típica da mente dos humanos) ao terreno dos quanta é o que procuramos fazer nesta seção. A semiose mais completa de organismos como os nossos não tem que ser enxergada como radicalmente distinta, separada da semiose do restante do 
universo, caso se aceite que a dualidade onda-corpúsculo (de matéria e de luz) é, por igual, uma dualidade iconicidade-indicialidade.

Uma esquematização resumirá o que está implicado no atual raciocínio:

Tabela 1 - Semiose da matéria e semiose abarcadora da atividade mental

\begin{tabular}{|c|c|c|c|}
\hline \multicolumn{4}{|c|}{$\begin{array}{c}\text { SEMIOSE DA MATÉRIA (OS QUANTA - 1. E 2.) E SEMIOSE } \\
\text { ABARCADORA DA ATIVIDADE MENTAL } \\
\text { (OU DE TERCEIRIDADE SEMELHANTE À HUMANA - 3.): }\end{array}$} \\
\hline $\begin{array}{l}\text { 1. Primeiridade } \\
\text { (semiose quân- } \\
\text { tica) }\end{array}$ & $\begin{array}{c}\text { iconicidade } \\
\text { (similaridade) }\end{array}$ & $\begin{array}{l}\text { ondas de maté- } \\
\text { ria (amplitudes } \\
\text { e quadrado das } \\
\text { amplitudes), } \\
\Psi \text { e }|\Psi|^{2}\end{array}$ & $\begin{array}{l}\text { continuidade, } \\
\text { possibilidade e } \\
\text { probabilidade } \\
\text { (quadrado das } \\
\text { amplitudes) }\end{array}$ \\
\hline $\begin{array}{l}\text { 2. Secundidade } \\
\text { (semiose quân- } \\
\text { tica após uma } \\
\text { medição ou em } \\
\text { decoerência) }\end{array}$ & $\begin{array}{l}\text { indicialidade } \\
\text { (contiguidade) }\end{array}$ & $\begin{array}{l}\text { partículas } \\
\text { detectadas }\end{array}$ & $\begin{array}{l}\text { descontinuidade } \\
\text { (colapso da } \\
\text { função de onda) } \\
\text { que irá acabar } \\
\text { gerando objetos } \\
\text { macroscópicos, } \\
\text { entre os quais } \\
\text { seres vivos }\end{array}$ \\
\hline $\begin{array}{l}\text { 3. Terceiridade } \\
\text { (leis como hábi- } \\
\text { tos naturais; } \\
\text { mentes como as } \\
\text { humanas) }\end{array}$ & $\begin{array}{c}\text { simbolismo } \\
\text { peirciano, } \\
\text { hábito } \\
\text { (convencionali- } \\
\text { dade } \\
\text { por um lado; } \\
\text { naturalidade } \\
\text { por outro) }\end{array}$ & $\begin{array}{l}\text { interpretan- } \\
\text { te dinâmico } \\
\text { simbólico, típico } \\
\text { de seres vivos } \\
\text { (que verão a } \\
\text { Primeiridade e } \\
\text { a Secundidade } \\
\text { quânticas acima } \\
\text { como "dualidade } \\
\text { onda-partícula") }\end{array}$ & $\begin{array}{c}\text { descontinuida- } \\
\text { de também na } \\
\text { relação simbó- } \\
\text { lico-linguística } \\
\text { entre signos e } \\
\text { objetos (micro e } \\
\text { macroscópicos, } \\
\text { concretos ou } \\
\text { abstratos) }\end{array}$ \\
\hline
\end{tabular}


Um dado intrigante resulta da combinação de duas sequências de informação ligadas ao presente esquema. Ei-las a seguir.

1) A medição que provoca o colapso da função de onda pode ser feita pelo sujeito humano ou não. Não tem sido possível, todavia, eliminar de todo este último da Mecânica Quântica, como ressalta Osvaldo Pessoa Jr. em artigo datado de 2001, que não perdeu a sua atualidade: “[...] ao final de 75 anos de Mecânica Quântica, o sujeito epistemológico ainda não conseguiu ser exorcizado da teoria"21 (PESSOA Jr., 2001, p. 20, grifo nosso). Na esquematização em foco, decorrente do nosso paralelo Peirce-Física Quântica, tal aspecto corresponde (implicitamente) à "passagem" da Primeiridade para a Secundidade, sobretudo.

2) No mesmo esquema, no "passo" da Secundidade para a Terceiridade, voltamos a encontrar a (implícita) figura do sujeito, e como é este que, em interação coletiva, de caráter necessariamente social, efetua a simbolização linguística (criação de signos mais convencionais), devemos considerá-lo aqui um sujeito também ontológico (além de epistêmico, óbvio), com mais liberdade criativa ou menor dependência das constrições do mundo físico do que no caso anterior.

Combinando as duas sequências em questão, notaremos logo a noção de sujeito em ambas (o dado intrigante anunciado parágrafos acima). Nada disto prova, porém, que algo como a consciência seja o fator a provocar o colapso da onda de matéria; no entanto, tudo isto envolve o sujeito humano em todas as facetas do trirrealismo peirciano-quântico, de um jeito ou de outro... Enredamento numa "cosmossemiose", acreditamos: participação intensa dos homens na realidade do univer-

21 O sujeito na física quântica. Disponível em: http://www.fflch.usp.br/df/opessoa/Sujeito.pdf 
so, ao mesmo tempo em que, tanto criativamente quanto nos limites das suas possibilidades, eles a mimetizam, a refletem. Refleti-la, mimetizá-la de maneira não servil tem sido um fator decisivo para a nossa sobrevivência enquanto espécie.

Ainda observando o esquema proposto, percebemos que nele há o que poderíamos considerar o jogo (ou dialética complementar, não hegeliana) entre continuidade e descontinuidade. Para tal consideração fornece Ramayana Gazzinelli uma boa imagem. A "quantização de uma grandeza física" implica que "ela varia descontinuamente, por saltos", o que não significa que a continuidade desapareça da natureza: "Para visualizar essa ideia de modo simples, você pode tomar como imagem uma torneira que goteja - a água flui de forma contínua no encanamento, cai em gotas (os quanta de energia) e toma novamente a forma contínua na bacia" (GAZZINELLI, 2013, p. 30). À iconicidade (onda de possibilidade, continuidade, Primeira categoria) e à indicialidade (colapso, decoerência, partícula detectada, descontinuidade, Segunda categoria) o humano simbolismo verbal (Terceiridade) se conecta - ou sobre elas se erige. Não fosse assim, com certeza o homo sapiens jamais se revelaria "sabido" o suficiente para inventar (ou aprender a inventar) as suas torneiras gotejantes, o que, afinal, envolve a Terceira categoria - sejamos físicos, bombeiros ou leigos a tratar do assunto.

Não menosprezamos explicações diversas das atuais para o fato de que o mesmo homo sapiens é um incansável forjador de símbolos vocabulares (e não vocabulares); o presente entendimento, entretanto, soa-nos como uma explicação plausível, de feição geral, situada no âmago da physis, não somente das formações sociais, que, sem dúvida alguma, exercem o seu (enorme) papel na geração de tal simbolismo. Postulamos que a natureza grupal dos seres humanos os leva 
à criação de símbolos verbais porque o cosmo carrega a possibilidade para tal: a descontinuidade que já vige na sua estruturação atômica e subatômica viabiliza a existência de objetos variados, aglomerados cada vez maiores de elétrons, quarks, glúons, etc. - e, percebendo esses objetos, a nossa mente, em seu longo processo darwinista de evolução, efetuou e prossegue efetuando "saltos" de fonemas (ou de grafismos, ou de cores, ou de sons não linguísticos, etc.) para as coisas (concretas ou não) com as quais, para sobreviver, precisamos lidar.

Descontinuidade relativa aos quanta, numa parcela do real; descontinuidade na nomeação dos macro-objetos do mundo, em outra parcela: assim como há o colapso descontínuo da onda em forma de partícula, por observação ou decoerência, existe a passagem descontínua da percepção das coisas para o campo dos signos arbitrários que irão representá-las, os símbolos linguísticos, elaborados pelas nossas mentes, que, sabendo-o ou não, dependem da lógica do quantum. Ocorre a mudança do potencial ao atual já no setor não humano da realidade, na matéria sem consciência: o referido colapso quântico; dá-se também a nomeação do objeto dinâmico como signo simbólico-verbal no setor humano da realidade, na matéria com consciência que somos: aqui, o evento descontínuo é a associação dos vocábulos às coisas, seja por lei, regra, hábito ou convenção... Acreditamos que a segunda ocorrência se efetue porque existe a primeira, com a sua lógica estranha - e se o homo sapiens e os seus antecessores realizaram aquela foi porque eles estão inseridos na physis, aprendendo a observar os seus princípios, para a construção dos melhores (e dos piores) mundos no que chamamos história - cuja arena palpável é a Secundidade, cheia de "som e fúria", de "sangue e areia", de dados sombrios como a utilização da fusão nuclear para a construção de bombas de 
hidrogênio (a mesma fusão que é já a fonte natural de energia das estrelas), mas também de aspectos positivos, como a medição da idade do cosmo ou a construção de uma sonda espacial - Voyager - com capacidade comprovada de sair do nosso sistema solar...

Claro que, relacionado ao que afirmamos acima, existe o fato de que a nossa espécie percebeu regularidades (baseadas em ciclos ou não) no seu meio ambiente imediato e também nos céus: retorno das estações, "reaparição" de astros, quedas de objetos, etc. Ora, regularidades assim, manifestando-se em concreto na Secundidade, implicam Terceiros, mais tarde generalizáveis como leis (acertadas ou falhas, não importa agora). Esta dimensão mais previsível do real decerto também incitou os homens a criar símbolos verbais: signos de caráter genérico, como a palavra "árvore", que serve para qualquer árvore, e mesmo uma especificação arbórea como "cipreste" significará qualquer cipreste do mundo, para um bom conjunto de falantes. Tal mimetização "antropossemiótica" da physis, envolvendo a Terceiridade, é perfeitamente articulável às iconicidade (Primeiridade) e indicialidade (Secundidade) naturais antes postuladas, vistas estas em termos de condição de possibilidade para a elaboração de semioses simbólicas idiomáticas - que acreditamos próprias apenas do fator da realidade universal denominado "vida" 22 , mesmo que algum dia concluamos que ela (incrivelmente) só exista na Terra.

Uma afirmativa de Vlatko Vedral nos ajudará a acentuar o ponto de vista presente. Diz ele: "O espaço e tempo [...] são dois dos conceitos clássicos mais fundamentais, mas de

22 Parece-nos que a Terceiridade é uma característica ampla do universo conhecido, ao passo que o símbolo linguístico (um dos fatores da Terceiridade) é algo restrito à atuação de seres vivos. Claro, há possibilidade de equívoco na segunda parte (a restritiva) da nossa afirmação. Falibilismo peirciano, de qualquer modo, ou seja, mesmo se errarmos, estaremos em acordo com a lógica do pensador! 
acordo com a mecânica quântica são secundários. Os emaranhamentos são primários. [...] Devemos explicar o espaço e o tempo como algo que emerge de uma física sem espaço ou tempo" (VEDRAL, 2011, p. 35). O raciocínio deste cientista auxilia-nos no entendimento de algo, em parte trivial, em parte surpreendente: seja considerada de uma perspectiva peirciana ou outra (a derivada de Saussure, a de Lótman, etc.), a semiose humana tampouco é a mais fundamental na realidade (aqui se acha a trivialidade), sendo secundária em relação à iconicidade e à indicialidade já próprias da dualidade onda-partícula da matéria e da luz, também uma semiose, embora complementar (aqui se acha a surpresa, supomos). Esta dualidade é que é básica. Assim, o possível antropomorfismo com que virmos o processo ficará circunscrito aos termos que inventamos para lidar com ele: palavras como "Primeiridade", "Secundidade”, “Terceiridade", "signo", "objeto", "interpretante", "ícone", "índice”, "símbolo", "semiose”, "dualidade”, entre muitas outras... Tal antropomorfismo, todavia, não dirá respeito aos objetos visados por tais palavras, às características internas destes mesmos objetos, assim como, por exemplo, o termo "emaranhamento" é, obviamente, um símbolo verbal (logo, um signo humano) que nomeia um dos fatos quânticos mais espantosos da natureza... O Princípio Antrópico (ou relativo ao homem) é dependente ("emerge") de uma cosmossemiose mais básica, na qual nos achamos imersos, não a podendo enxergar de fora, numa situação de exterioridade, em termos de Mecânica Quântica. Neste passo, "cosmossemiose" significa: aceitar a imersão da nossa humana semiose na do universo conhecível, a nossa dependência da sua "sintonia fina" de leis, mimetizando como pudermos o seu inerente triadismo... A vida de que temos ciência (e nós em especial, no seu interior) prossegue(m), adaptando-se a isto. 
Segundo o filósofo, o próprio homem é um signo $(C P$, 5.310-317); acrescentamos: feito de matéria afinal quântica, ela mesma de caráter semiótico, pelo que dissemos. Ora, em termos de demonstração não quantitativa, mas verbal, não temos melhores argumentos para a hipótese de que somos triádicos, porque a realidade universal conhecida o é também, falando sem "antropolatria". Realidade universal conhecida: por ora, apenas os 4 ou $5 \%$ do que se detecta no cosmo. Dia e noite estamos nela imersos (ao menos). E se for provado que o cosmo (ou até um multiverso) apresenta mais dimensões, ou que o resto da realidade ( $95 \%$ ou mais) não é apenas triádico? Provavelmente, não importará, em termos do triadismo já consolidado: a nossa atual percentagem de percepção do todo não parece errada, perante o que vamos descobrindo; teremos, sim, que ampliar os nossos predicados categoriais.

Busquemos agora a "síntese da síntese" do que, nesta seção, defendemos: a) além da noção de contínuo, a dualidade onda-partícula implica descontinuidade, no microdomínio dos quanta, como ainda pressupõe iconicidade (onda) e indicialidade (partícula, corpúsculo), que são processos sígnicos, exemplos de semiose; b) o simbolismo de animais falantes como os humanos, sendo um dado de semiose, implica também descontinuidade, no macrodomínio que envolve os signos e os objetos com os quais lidamos. Enxergar interconexões em tudo isto não nos parece algo abusivo.

\section{Um exemplo (literalmente) luminoso da ligação da nossa semiose com a do universo}

Vejamos um caso em que ícones e índices físicos, por um lado, e simbolismo humano (ou verbal), por outro, se acham 
inter-relacionados. Um caso que, como tal, é algo específico, mas que revela ter um alcance enorme, pois sem ele a nossa percepção do meio-ambiente seria diversa. Ele envolve simultaneamente os domínios quântico, biológico e psíquico, abarcando, por ordem respectiva, a luz, o nosso sistema sensorial e o inconsciente freudiano (ou a física, a biologia e a psicanálise).

Desde o final dos anos 1980, através de experiências controladas, as neurociências e a terapia cognitiva vêm confirmando a concepção de inconsciente individual, o que comprova, ao menos, a solidez da pedra fundamental da teoria elaborada por Sigmund Freud (embora outros aspectos da mesma teoria ainda não sejam passíveis de experimentação). Um dos especialistas no assunto (Marco Callegaro) sintetiza tal confirmação, retomando a imagem freudiana de ser a psique um iceberg: neste, o topo (ou a consciência) ocupa não mais do que cerca de um décimo do conjunto; já a parcela submersa vale pelos aproximados noventa por cento que restam (o inconsciente). Diz Callegaro:

Se concordarmos com a metáfora da mente como um iceberg, surge o problema de identificar o tamanho relativo da parte escondida abaixo da superfície (o processamento inconsciente) e do topo (a consciência). [...] Nosso [...] sistema visual sozinho responde pelo processamento de 10 milhões de bits por segundo, enquanto todos os outros sentidos somam mais de 1 milhão de bits a cada segundo.

[...] Se adotarmos uma média de 50 bits a cada segundo (um valor considerado otimista) como a capacidade de processamento consciente, chegamos à conclusão [...] de que o processamento inconsciente é cerca de 200 mil vezes maior do que o consciente (CALLEGARO, 2011, p. 26-27).

Dados numéricos de grande impacto: em meio ao processamento de 11 milhões de bits (ou unidades da teoria da 
informação utilizada nos experimentos), 10 milhões concernem ao "sistema visual", aos nossos olhos. Ora, estes processam informação de natureza óptica, ligada à luz visível ou parcela do eletromagnetismo que conseguimos perceber - em derradeira análise, os fótons, cujo comportamento quântico bem se conhece. Este último, ademais, pressupõe a dualidade onda-partícula. Esta, por sua vez, em termos semióticos, ora se revela icônica (quando em estado de onda), ora indicial (quando corpuscular). Claro, o nosso sistema visual é, de fato, um aparelho (biológico) de medição de fótons, um detector clássico (macroscópico) de informações quânticas (microscópicas), que nos atingem em formato luminoso. Tal detecção lida, pois, com a impressionante, avassaladora quantidade de bits que nos chegam a cada segundo (os 10 milhões citados). Se, no máximo, apenas uns 50 bits informativos podem ser absorvidos conscientemente, no processo, então precisamos admitir algo: como assinala o físico Leonard Mlodinow, em seu livro Subliminar, possuímos uma espécie de "cérebro duplo", tanto consciente quanto inconsciente (MLODINOW, 2013, p. 15-125).

A evolução nos deu uma mente inconsciente porque é ela que permite nossa sobrevivência num mundo que exige assimilação e processamento de energia tão maciços. Percepção sensorial, capacidade de memória, julgamentos, decisões e atividades do dia a dia parecem não exigir esforço - mas isso só porque o esforço demandado é imposto sobretudo a partes do cérebro que funcionam fora do plano da consciência (MLODINOW, 2013, p. 43).

Dos 10 milhões de bits que nos cabem, associados à visualidade, quer o cérebro consciente quer o inconsciente assimilam e processam um fator da natureza que, de acordo com 
o que antes argumentamos, é já semiótico: a luz, a qual, segundo a Mecânica Quântica, é algo ondulatório-corpuscular, ou seja, em termos aqui utilizados, icônico-indicial, o que consideramos agora uma "dualidade Primeiridade-Secundidade", ainda peircianamente falando - e, dada a vastidão daquele número de bits, não é difícil supor que uma Terceiridade verbal, linguística, de feitio necessariamente simbólico, dependa também da absorção sensorial, corpórea, de uma manifestação física das duas primeiras categorias de Peirce, conforme postulamos (a luz considerada como onda e como partícula, sempre de maneira complementar).

Quando enxergamos o mundo ao nosso redor, em linhas muito gerais acontece o seguinte: os raios de luz (informações visuais) que as coisas refletem entram pelos nossos olhos através da córnea; a córnea e a lente que se estende pelo interior de cada olho refratam tais raios de luz, transformando-os em imagens invertidas (de ponta-cabeça) na retina, localizada atrás da lente; ali, milhões de fotorreceptores captam as cores (os cones) e o preto e o branco (bastonetes); impactados pela luz, os fotorreceptores disparam impulsos nervosos, que compõem as imagens invertidas; estas imagens (ou conjunto de impulsos nervosos) são conduzidas ao cérebro, pelo nervo óptico; no cérebro, todo este aglomerado de informações (ou interpretantes ainda imediatos) será, em microssegundos, ativamente interpretado, processado neurologicamente, em termos de imagens coloridas e tridimensionais; a interpretação em causa corrige ainda a inversão das imagens, virando-as para cima. Como não ver em tudo isto uma semiose peirciana? Raios de luz refletidos pelas coisas (objetos dinâmicos) são signos destas (destes), constituídos por fótons (entidades duais, insistamos: ondas-ícones, partículas-índices); o cérebro que os analisa - em trabalho inconsciente - cria agora interpretantes dinâmicos vi- 
suais para os mesmos, numa operação rápida, eficaz e complexa; dificilmente estes interpretantes dinâmicos visuais não são acompanhados por interpretantes também dinâmicos verbais (símbolos, na vasta acepção de Peirce).

Tão ativo é o trabalho cerebral acima descrito (em seus pormenores mais salientes) que o neurocientista Jonah Lehrer chega a afirmar: "O fato é que nosso mundo de formas existe apenas nesse estágio final do processamento neural, dentro de [...] saliências cranianas muito distantes da luz do mundo exterior". E mais: "Se removêssemos a nossa autoconsciência do mundo, se enxergássemos com a honestidade intelectual dos nossos globos oculares, não veríamos nada mais do que pontos solitários de luz, brilhando em um espaço amorfo" (LEHRER, 2010, p. 177-178, respectivamente). (No discurso do cientista, "autoconsciência" vale por mente, psique, consciência e inconsciente associados, geradores de interpretantes.)

Claro, de modo nenhum pretendemos "derivar" a verbalidade da visualidade oriunda da luz, da energia eletromagnética! 0 que destacamos é a probabilíssima importância da informação luminar para a constituição da semiose linguística, tendo em vista o número astronômico de bits "fotônicos" que nos bombardeiam, a cada segundo. Robustece no presente raciocínio a lembrança de que, em várias culturas, os homens inventaram sistemas de escrita (signos ópticos bem pouco fonéticos na sua origem histórica) para que o fluxo da fala não se perdesse no do tempo: precisamente um reforço visual para a discursividade, o verbalismo (Terceiridade). Que o digam aqui o $\mathrm{A}$, o qual, invertido, foi outrora o pictograma de uma cabeça de boi, e o 0 , um olho, nada menos...

Outra vez, o simbolismo tipicamente humano afigurase-nos mergulhado numa semiose cósmica mais fundamental, o que vimos já Peirce apontar com a sua afirmativa “Todo 
o Universo é penetrado por signos, se não se compõe até somente de signos"... Agora, tal semiose universal nos impressiona em condição de luz, de eletromagnetismo, impactando o "cérebro duplo" do homo sapiens: como os seus antecessores, este sempre esteve conectado à physis; fiquemos, pois, atentos ao que as ciências (e outras modalidades de conhecimento) vierem a descobrir em termos de tal conexão, seja esta corporal ou psíquica, ou melhor, "psicofísica" - uma vez que a mente, analisada em termos também próximos aos métodos das ciências naturais, entrou no jogo do conhecimento (ou de autoconhecimento), quer como fator que interpreta, quer como objeto de saber, sobretudo, em exemplificação da tríade signo-objeto-interpretante (já que sem signos não se interpreta coisa alguma).

Tendo em vista o que dissemos até aqui, não espanta que, na primeiríssima página do prefácio ao seu Subliminar, Leonard Mlodinow remeta a uma experiência de Peirce e seu assistente Joseph Jastrow, efetuada em 1884. Nela, ambos mediram, concreta e quantitativamente, a capacidade de o sujeito humano discriminar pesos diferentes, mas tão leves que, de modo consciente, ele não poderia discriminar. Embora a experiência Peirce-Jastrow fosse uma adaptação de uma anterior, do fisiologista E. H. Weber (1834), Mlodinow conclui: "Essa foi a primeira demonstração científica [a de Peirce-Jastrow] de que a parte inconsciente da mente dispõe de conhecimentos que escapam da parte consciente" (MLODINOW, 2013, p. 8).

Inconsciência, consciência, mente, matéria, luz: semioses, inter-relações que nos interessam, menos por elas mesmas, mais por revelarem o pertencimento íntimo dos humanos que somos ao cosmo. 


\section{REFERÊNCIAS}

ALMEIDA, A. M. O. de. Correlações quânticas no espaço de fases. São Paulo: Livraria da Física, 2010.

BÄCHTOLD, M. L'interprétation de la mécanique quantique: une approche pragmatiste. Paris: Hermann Éditeurs, 2008.

BITBOL, M. Física e filosofia do espírito. Tradução de A. Rabaça. Lisboa: Instituto Piaget, 2001.

BOHR, N. Física atômica e conhecimento humano. 4. reimpr. Tradução de V. Ribeiro. Rio de Janeiro: Contraponto, 2008.

CALLEGARO, M. 0 novo inconsciente. Porto Alegre: Artmed, 2011.

CREASE, R. P. As grandes equações. Tradução de A. Cherman. Rio de Janeiro: Zahar, 2011.

EISBERG, R.; RESNICK, R. Física Quântica. Tradução de P. C. Ribeiro, Ê. F. da S. de M. F. Barroso e M. F. Barroso. Rio de Janeiro: Elsevier, 1979.

FEYNMAN, R. Sobre as leis da física. Tradução de M. Novaes. Rio de Janeiro: Contraponto, 2012.

. Mecânica Quântica. In: Lições de física. Tradução de A. R. da Silva e S. R. A. Canuto. Porto Alegre: Bookman, 2008, v. 3. FEYNMAN, R.; HIBBS, A. R. Quantum mechanics and path integrals. Emended edition. Mineola, New York: Dover Publications, 2010.

FREIRE Jr.; OLIVAL et al. Teoria quântica. Campina Grande: EDUEP/Livraria da Física, 2010.

GAZZINELLI, R. Quem tem medo da Física Quântica? Belo Horizonte: Editora da UFMG, 2013. 
GOSWAMI, A. O universo autoconsciente. 2. ed. 1. reimpr. Tradução de R. Jugmann. São Paulo: Aleph, 2010.

GREENE, B. O tecido do cosmo. 2. reimpr. Tradução de J. V. Filho. São Paulo: Cia. das Letras, 2005.

HALLIDAY, D.; RESNICK, J. W. Fundamentos da física: óptica e física moderna. 9. ed. Tradução e revisão técnica de R. S. de Biasi. Rio de Janeiro: LTC, 2012.

HEISENBERG, W. Física e filosofia. 4. ed. Tradução de J. L. Ferreira. Brasília: Editora da Universidade de Brasília, 1999.

HERBERT, N. A realidade quântica. Tradução de M. C. Moura. Rio de Janeiro: Francisco Alves, 1989.

HEWITT, P. G. Física conceitual. 11. ed. Tradução de T. F. Ricci. Porto Alegre: Bookman, 2011.

HOUSER, N. Prólogo. Disponível em: www.avizora.com/ publicaciones/biografias/textos/textos_p/0029_peirce_charles_ sanders.htm. Acesso em: 07 ago. 2013.

IBRI, I. A. Kósmos Noetós. São Paulo: Perspectiva/Hólon, 1992. KAKU, M. Mundos paralelos. Tradução de T. M. Rodrigues. Rio de Janeiro: Rocco, 2007.

KRAUSE, D. Tópicos em ontologia analítica. Santa Catarina: Universidade Federal de Santa Catarina, 2011. Disponível em: http://cfh.ufsc.br/ dkrause/pg/TopicosOntologia.pdf. Acesso em 18 out. 2013.

LEHRER, J. Proust foi um neurocientista. Tradução de F. Santos. Rio de Janeiro: BestSeller, 2010.

LOPES, J. L. A estrutura quântica da matéria. 2. ed. Rio de Janeiro: Editora UFRJ, 2005. 
MACHADO, K. D. Equações diferenciais aplicadas à física. Ponta Grossa: UEPG, 1999.

MACHADO, L. Proposição de um realismo semiótico peirciano para uma das versões da física quântica. CASA: Cadernos de semiótica aplicada, v. 11 n. 1. Araraquara: julho de 2013, p. 3-21. Disponível em: http://seer.fclar.unesp.br/casa. Acesso em: 27 mar. 2014.

MLODINOW, L. Subliminar. Tradução de C. Carina. Rio de Janeiro: Zahar, 2013.

NÖTH, W. A semiótica no século XX. 2. ed. São Paulo: Annablume, 1999.

OLIVEIRA, I. S. Física moderna. 2. ed. São Paulo: Livraria da Física, 2010.

. Revisitando a estranha natureza da realidade quântica.

Ciência hoje. Disponível em: http://cienciahoje.uol.com. br/revista-ch/2011/282/revisitando-a-estranha-natureza-darealidade-quantica. Acesso em 06 set. 2011.

OSNAGHI, S. A dissolução pragmático-transcendental do "problema da medição" em Física Quântica. Cadernos de história e filosofia da ciência, v. 15, série 3, n. 1. Campinas: janeiro-junho de 2005, p. 79-125. http://www.cle.unicamp. br/cadernos/pdf/Stefano\%25200snaghi.pdf. Acesso em 20 out. 2013.

PATY, M. A física do século XX. Tradução de P. Mariconda. Aparecida, SP: Ideias \& Letras, 2009.

PEIRCE, C S. Semiótica. Tradução de J. T. C. Netto. São Paulo: Perspectiva, 1977.

. Collected papers. Ed. Charles Hartshorne, Paul Weiss e Arthur Burks. Cambridge, Massachusetts: Harvard University 
Press, 1931-1935, 1958, 8 vols. (Referidos abreviadamente como CP.)

PENROSE, R. A nova mente do rei: computadores, mentes e as leis da física. Tradução de W. Dutra. Rio de Janeiro: Campus, 1991.

PESSOA Jr., O. Conceitos de física quântica. São Paulo: Editora Livraria da Física, 2006. Vol. I e II.

. O sujeito na física quântica, 2001. Disponível em: http:// www.fflch.usp.br/df/opessoa/Sujeito.pdf. Acesso em 21 mai. 2013.

PINTO, J. 1, 2, 3 da semiótica. Belo Horizonte: Editora UFMG, 1995.

PIRES, A. S. Enigmas do universo. São Paulo: Editora Livraria da Física, 2012.

RODRIGUES, A. D. Introdução à semiótica. Lisboa: Editorial Presença, 1991.

SAKURAI, J. J.; NAPOLITANO, J. Modern quantum mechanics. 2nd ed. Boston: Pearson Education, 2011.

SANTAELLA, L. A teoria geral dos signos. São Paulo: Ática, 1995.

VEDRAL, V. A vida em um mundo quântico. Scientific American Brasil, n. 110. São Paulo: Ediouro Duetto Editorial, julho de 2011, p. 30-35.

Artigo recebido em janeiro de 2014 e aprovado em maio de 2014.

Disponível em: http://seer.fclar.unesp.br/casa 